ROCZNIKI PEDAGOGICZNE

Tom 12(48), numer $2-2020$

DOI: http://dx.doi.org/10.18290/rped20122-7

\author{
JOANNA MAJCHRZYK-MIKUŁA \\ MARCELINA KACPRZAK
}

\title{
ARTETERAPIA INSPIRACJĄ DLA PEDAGOGIKI
}

\begin{abstract}
WSTĘP
Arteterapia (zwana również autoterapią), czyli terapia poprzez sztukę, polega przede wszystkim na uwolnieniu swoich emocji za pomocą tworzenia różnych prac plastycznych - wszelka aktywność twórcza wykonywana jest za pomocą różnorakich technik graficznych. Prócz arteterapii rozumianej jako „leczenie malunkiem” w skład opisywanej terapii wchodzą m.in. muzykoterapia, choreoterapia czy biblioterapia. ,Rekonwalescencja” przez sztukę wpływa pozytywnie na rozwój emocjonalny najmłodszych, pozwalając na korygowanie własnych uczuć oraz niwelowanie negatywnych odczuć. Najważniejszym elementem ,kuracji” nie jest końcowy efekt, a sam proces pracy - to niezwykle ważne w przypadku stosowania arteterapii u osób z rodzin dysfunkcyjnych oraz z obniżoną sprawnością intelektualną. Sama autoterapia stanowi jedną z popularnych, choć nie do końca docenianych, terapii stosowanych wobec dzieci i młodzieży, zaś jej odbiorcy niejednokrotnie niechętnie biorą udział w organizowanych zajęciach. Ich obiekcje wynikają zazwyczaj ze strachu przed ocenianiem przez prowadzącego lub też uważania, że owe warsztaty są skierowane wyłącznie do osób utalentowanych - plastycznie, ruchowo czy też muzycznie.
\end{abstract}

Dr hab. JoAnna MaJChrzYK-MikuŁA, prof. UJK, Instytut Pedagogiki, Uniwersytet Jana Kochanowskiego w Kielcach, Filia w Piotrkowie Trybunalskim; e-mail: drasma@wp.pl; ORCID: https://orcid.org/0000-0003-2920-0447.

Mgr MARCElina KACPRZAK, Świetlica Środowiskowa „TOMY”w Tomaszowie Mazowieckim; e-mail: marcelina5@onet.pl. 


\section{POJĘCIE ARTETERAPII}

Arteterapia coraz częściej wzbudza zainteresowanie wśród pedagogów, którzy stosują ją jako formę pracy z drugim człowiekiem (niezależnie od jego wieku), u którego występują objawy nieprawidłowości rozwoju lub zachowaniu (Skwarek, Szulc, 2017). Jest ona jednym ze sposobów oddziaływania psychoterapeutycznego, mogącego efektywnie wspierać terapię farmakologiczną zaburzeń psychicznych na każdym etapie ich powstawania. Posiada różnorakie przeznaczenie, od terapii i diagnozy począwszy, a skończywszy na uaktywnianiu, rewalidacji, wyciszeniu oraz prewencji zaburzeń na tle psychicznym. Sama definicja arteterapii ma bardzo szerokie znaczenie, jednak w przypadku jednej z metod wychowywania dzieci i młodzieży można pojmować ją jako psychoterapię wykorzystującą sztuki plastyczne do uzewnętrzniania i przepracowania kłopotów oraz trudności wychowanka. Praktyka oparta jest przede wszystkim na teoriach psychologicznych, przede wszystkim na psychoanalizie, podejściu behawioralno-poznawczym oraz przeświadczeniu, że postępowanie twórcze ma właściwości rozwojowe oraz terapeutyczne (Stańko, 2009a). Jak twierdzi jedna z autorek „Zakłada ona oddziaływanie za pomocą sztuki na organizm ludzki jako całość, stwarza możliwość rozładowania wewnętrznych konfliktów, tłumionych emocji, umożliwia osiągnięcie katharsis, czyli oczyszczenia, które wpływa integrująco na osobowość jednostki” (Grudziewska, 2010).

Charakterystyczne dla niej jest twórczo-terapeutyczne wykorzystywanie niewerbalnego procesu komunikowania oraz użyciu skupiających się na pacjencie środków i procesów artystycznych w obszarze korelacji psychoterapeutycznej. Postępowanie kreatywne albo jego wynik jest kolejnym składnikiem terapii, będącej fundamentem do stawiania specjalistycznych diagnoz, postanowień oraz przedsięwzięcia interwencji wobec drugiej osoby (Blotevogel, Hitzeler, Stegemann, 2015).

U podstaw pozytywnego wyniku przeprowadzonej twórczej terapii leżą:

- niwelowanie lub zlikwidowanie wewnętrznego napięcia;

- przedstawianie niepoddającego się artykulacji, świadomego lub nie materiału uczuciowego;

- wspieranie degresji w służbie jaźni;

- czynność regulująca, wspomagająca odczucie swojej własnej wartości w odniesieniu do egocentrycznej gratyfikacji, będącej efektem kreatywnej działalności; 
- wyrażenie traumatycznych przeżyć za pomocą wszelkich artystycznych metod;

- rozluźnienie neurotycznej defensywy;

- wolne od strachu obchodzenie się z fantazjami;

- wzbudzenie do działalności i umocnienie duchowej atrybucji sprawowania kontroli (danie pacjentowi pewności, że to on sam kreuje swoje otoczenie) (Blotevogel, Hitzeler, Stegemann, 2015). Takie podejście do tworzenia czegokolwiek nie dla końcowego efektu, ale dla samego faktu kreowania sprawia, że młodzi ludzie mają możliwość ,,wyżycia emocjonalnego”, lepszego zrozumienia siebie samego. Nie będąc ocenianym za talent, mając ,,wolną rękę" w tworzeniu swego dzieła, można bez przeszkód i skrępowania przenieść wszystkie swoje smutki i radości na wykonywany twór.

\section{RODZAJE ARTETERAPII I ICH CHARAKTERYSTYKA}

Jednym z popularniejszych rodzajów arteterapii jest muzykoterapia uważa się, że kontakt człowieka z muzyką skutkuje jego większym uwrażliwieniem, ,wczuciem się" w sytuację drugiej strony, jak również lepszym rozwojem osobowości. Sama terapia jest charakteryzowana jako jedna z metod psychoterapii korzystająca z muzyki i jej ,,składników” do pobudzenia, strukturalizacji oraz wyrazistości uczuciowej, emocjonalnej oraz porozumiewania się niewerbalnego w procesie rozpoznania, kuracji i rozwoju usposobienia człowieka (Konieczna, 2004).

Leczenie dźwiękiem można podzielić na kilka odmian, biorąc pod uwagę możliwości jego wykorzystania:

- muzykoterapia profilaktyczna - używana w celu prewencyjnym, stosująca właściwy materiał muzyczny dla aktywizacji albo zrelaksowania;

- muzykoterapia kliniczno-diagnostyczna - zachodzą w niej czynności powzięte przez specjalistów medycznych;

- muzykoterapia adoptowana - czerpiąca epizodyczny materiał muzyczny celem zniwelowania stresu;

- muzykoterapia spontaniczna - wyraża emocje, które odczuwa pacjent w danym momencie;

- muzykoterapia naturalna - fundamentalnym materiałem muzycznym są odgłosy natury, takie jak szum morza czy śpiew ptaków (Konieczna, 2004).

Muzykoterapia często łączona jest z choreoterapią, dzięki czemu pacjent ma szansę na ekspresyjne wyrażanie przeżywanych uczuć i emocji. Terapia 
dźwiękami ma prawdopodobnie większe sposobności stosowania aniżeli inne elementy arteterapii - prócz bycia jedynie ,ttłem” innych rodzajów terapii przez sztukę, może stanowić jej fundament. Jest to niezwykle ważne, gdyż znając wartość i możliwości, jakie niosą ze sobą dźwięki, można stosować ją w celu rozwijania lub kształtowania wrażliwości u pacjenta, jego wyobraźni. Pozwala również uaktywnić emocje, jakie zostały zniekształcone albo zniwelowane przez samego młodego pacjenta. Ciekawym zastosowaniem muzykoterapii jest łączenie jej działania z zajęciami relaksacyjnymi - masażem, ćwiczeniami oddechowymi lub rozluźniającymi, bajką terapeutyczną. Dodatkowo mnogość rodzajów samej muzyki sprawia, że można stosować ją praktycznie do każdych zajęć, niejako zapoznając dzieci z różnymi jej rodzajami, a tym samym ubogacając je kulturowo.

Innym rodzajem arteterapii jest wspomniana już choreoterapia, zwana także terapią tańcem. Definiowana jest jako: „terapeutyczne wykorzystanie ruchu jako procesu, poprzez który wspomagana zostaje emocjonalna i fizyczna integracja" (Kran, 2001). Traktuje ona ruch jako rodzaj psychoterapii dążącej do wypracowania przez pacjenta integracji psychofizycznej. Przy tym charakteryzuje się wielozakresowością i wielowymiarowością, gdyż wpływa na sferę uczuciową, ruchową, fizjologiczną, kognitywną, wolicjonalną, estetyczną, emocjonalną jak i strefę interakcji społecznych. Wyodrębnia się jej następujące rodzaje:

- choreoterapia specjalna - stosowana w przypadku osób poważnie poszkodowanych fizycznie;

- choreoterapia kondycyjna - zorientowana na osoby zdrowe fizycznie, której głównym celem jest poprawienie i skorygowanie ogólnej wydolności i zręczności ruchowej, stosowanej w celu prewencyjnym;

- choreoterapia sprawnościowa - wykorzystywana u ludzi ze zmniejszoną sprawnością fizyczną i dyskoordynacją ruchową (Konieczna, 2004).

Najważniejszym zadaniem w terapii tańcem jest doprowadzenie do odczucia przez dzieci własnej fizyczności i zwiększania własnej świadomości. Następuje to pod wpływem założenia, że historia życia jednostki jest zablokowana w układzie kostnym i mięśniowym, natomiast korzystne zmiany będą wpływały nie tylko na ciało, ale także na psychikę. Kolejnym celami choreoterapii jest wykształcenie właściwych warunków do interakcji z innymi ludźmi przez ruch i utworzenie wymogów (Konieczna, 2004).

Choreoterapia, podobnie jak terapia przez zastosowanie sztuk plastycznych, jest jedną z trudniejszych do wprowadzenia w grupie dzieci czy młodzieży. Jedynie nieliczne osoby $\mathrm{z}$ chęcią podejmują proponowane przez 
terapeutę zadania, wstydząc się własnego ciała, koordynacji ruchowej czy też obawiając się reakcji rówieśników. $Z$ tego powodu należy podkreślać, że wykonywane zadania nie mają na celu wyłonienie ,,najlepiej skoordynowanej osoby". Nauczanie i oswojenie się z własną fizycznością może doprowadzić do pozwolenia sobie, by poprzez ruch rozładować negatywne emocje.

Kolejną popularną metodą ,,leczenia przez sztukę” jest biblioterapia, która po raz pierwszy w Polsce została zdefiniowana w latach trzydziestych; uznawano ją za czynności terapeutyczne, gdzie głównym narzędziem aktywizującym jest książka (Ippoldt, 2003).

Współcześnie biblioterapia jest również określana jako ,leczenie książką", przy czym należy wspomnieć, że literatura jest dobierana nie tylko do wieku czytelników, ale także problemów, z jakim mają do czynienia. Najwygodniejszym i jednocześnie najbardziej możliwym do przeprowadzenia sposobem biblioterapii jest stosowanie wybranych fragmentów z powieści lub wiersza (Matras-Mastalerz, 2016). W przypadku tej metody pracy z grupą można zauważyć największe zaangażowanie dzieci w pracę, bowiem nie wymaga ona od nich umiejętności plastycznych lub muzycznych, nie obawiają się także oceniania przez pryzmat swojej koordynacji ruchowej. Dodatkowym atutem jest możliwość doboru tekstu do konkretnego problemu w taki sposób, by młody człowiek poczuł, że opisywane dylematy dotyczą większej liczby osób, nie tylko jego, a co więcej, że można znaleźć ich rozwiązanie. Niejednokrotnie zdarza się, że prowadzący zajęcia zachęca uczestników do wypowiedzenia się, w jaki sposób można rozstrzygnąć dane zagadnienie.

Prócz pokazywania, jak radzić sobie z kłopotliwymi sytuacjami, biblioterapia - podobnie jak inne formy leczenia przez sztukę - rozwija w pacjentach empatię, wspiera rozwój przystosowania społecznego, umiejętność słuchania innych, stara się zniwelować niską samoocenę (Czernianin, Czernianin, 2014).

„Każda bajka ma wartość moralną, kończy się morałem, który należy rozwinąć $\mathrm{w}$ rozmowie. Jedną $\mathrm{z}$ form jest poezjoterapia, czyli terapia wykorzystująca poezję, polegająca na czytaniu, recytowaniu, pisaniu wierszy" (Korodzińska-Grabowska, 2012).

Leczenie książką polega nie tylko na samym kontakcie z literaturą, ale również na tworzeniu pewnych elementów z nią związanych - mogą to być różne formy literackie, a także gry i zabawy związane z przedstawionym fragmentem. Zdarza się, że biblioterapia wykorzystuje w swojej terapii dramę. 
Nieco mniej znaną autoterapią jest zjawisko ,leczenia teatrem”, które można zaobserwować już w czasach starożytnej Grecji, kiedy to sztuka miała na celu wywołanie u widzów uczucia oczyszczenia, wzbudzenia w nich uczucia empatii, jak również nauki, w jaki sposób winni się zachowywać.

Teatroterapia antycypuje wychowanie dziecka przez teatr; sam termin definiowany jest jako metoda do wewnętrznego rozwoju i wzbogacenie osobowości spowodowane udziałem $w$ widowiskach teatralnych. Ta odmiana terapii ma uwalniający wpływ na umysł człowieka - możliwość wcielenia się w ,drugą osobę” zezwala na bycie przez chwilę kimś, kim zawsze chciało się być, zapomnieniu o swoich frustracjach i problemach oraz lepszemu przystosowaniu się do społeczeństwa (Konieczna, 2004).

Do rodzajów teatroterapii można zaliczyć:

- psychodramę, czyli spontaniczne przedstawienie sceniczne, które pozwala na uwidocznienie i ponowne przeżycie konfliktów interpersonalnych i intrapsychicznych w ramach terapeutycznych;

- dramę rozumianą jako metodę pomocniczą w nauczaniu różnych przedmiotów szkolnych lub samoistną metodę kształcenia osobowości człowieka poprzez rozwijanie wyobraźni i wrażliwości, uczenie aktywnej twórczości, kształcenie umiejętności współpracy z innymi ludźmi;

- pantomimę, czyli nieme widowisko sceniczne, w którym zdarzenia przekazywane są przez aktorów wyłącznie za pomocą ruchów, gestów, mimiki (Konieczna, 2004).

Ważna w teatroterapii jest praca grupowa, która niezwykle pozytywnie wpływa na jednostkę, dając jej poczucie przynależności, uczy demokracji, odpowiedzialności i współpracy. Grupa teatralna daje wrażenie bycia wyjątkowym, ale również uczy poszanowania drugiej osoby, umiejętności dochowania tajemnicy oraz słuchania innych (Skrzypczyk, 2013). Przy tym należy podkreślić, że jest ona jedną z niewielu terapii zajęciowych, których nie można przeprowadzać indywidualnie, wręcz przeciwnie - najlepsze efekty przynosi ona $\mathrm{w}$ momencie, kiedy zajęcia prowadzone są z co najmniej kilkoma osobami. Teatroterapię można z powodzeniem łączyć z innymi „,kuracjami” przez sztukę - muzykoterapię i/lub choreoterapię z pantomimą, biblioterapię z dramą, zaś ćwiczenia plastyczne można wykorzystać tworząc dekoracje do przedstawienia. Ciekawym jest połączenie teatroterapii z socjoterapią, gdzie wychowankowie odgrywają scenki odnoszące się do pewnych zachowań, najczęściej pozytywnych, aby nauczyć ich prawidłowych postępowań wobec innych. 


\section{PRZEBIEG ZAJĘĆ ARTETERAPEUTYCZNYCH}

Każde prawidłowo przeprowadzane zajęcie z arteterapii powinno składać z dwóch części:

- praktycznej, podczas której dzieci i młodzież biorą udział w „tworzeniu" różnorakich dzieł, mających na celu zniwelowanie negatywnych odczuć i wzmocnieniu tych pozytywnych;

- refleksyjnej (dyskusyjnej), gdzie uczestnicy wypowiadają się na temat swoich prac oraz odczuć towarzyszących im podczas zajęć; warunkiem dobrze przeprowadzonej części dyskusyjnej jest zapewnienie biorącym udział komfortu wypowiedzi oraz niezmuszania ich do brania udziału w rozmowie w momencie, kiedy czują się skrępowani lub są ku temu niechętni (Stańko, 2009a).

Przy przeprowadzaniu terapii należy pamiętać o najważniejszych zasadach, czyli:

- zasada stałości wpływu pedagogicznego;

- zasada zindywidualizowania sposobów i możliwości oddziaływania naprawczego;

- zasada cykliczności;

- zasada stopniowania problemów, mając na uwadze wieloaspektowość i predyspozycje percepcyjne wychowanka;

- zasada kompensacji nieprawidłowości pojmowana jako konieczność łączenia ćwiczeń czynności zniekształconych z treningiem funkcji ,,poprawnych" celem stworzenia odpowiednich mechanizmów kompensacyjnych;

- zasada korekcji nieprawidłowości bazująca na ćwiczeniu głównie czynności najbardziej zaburzonych oraz najmniej opanowanych umiejętności (Gładyszewka-Cylulko, 2011).

Mając na uwadze powyższe prawidła, należy pamiętać, że najważniejsze w arteterapii jest nawiązanie swoistego rodzaju więzi z wychowankiem; musi on czuć się swobodnie podczas zajęć, wiedzieć, iż ma prawo i możliwość wyrażania swoich emocji w sposób niekrzywdzący drugiej osoby ani jego samego. Często takie zajęcia są jedynym momentem, kiedy dziecko może odsłonić swoje prawdziwe ,,ja”, składające się z marzeń, lęków, porażek, sukcesów, strachu czy też potrzeb emocjonalnych.

Ważne jest, by grupa w której odbywają się zajęcia, była jak najbardziej jednorodna - przybliżona wiekowo, posiadająca podobne problemy oraz, co bywa pomijane, homogeniczna pod względem płci (dziewczynki często wstydzą się wypowiadać przy chłopcach i na odwrót). 


\section{PRZEBIEG PROCESU ARTETERAPII W ŚWIETLICY ŚRODOWISKOWEJ ,,TOMY”}

Na przełomie listopada i grudnia 2019 r. (przez pięć tygodni) przeprowadzono w świetlicy środowiskowej „TOMY” w Tomaszowie Mazowieckim badania mające stwierdzić, $w$ jaki sposób dzieci reagują na zajęcia $\mathrm{z}$ arteterapii. W badaniu wzięło udział 31 dzieci, w tym 14 chłopców i 17 dziewcząt. Wychowankowie placówki są w wieku od 7 do 12 lat.

Wykorzystano metodę obserwacji uczestniczącej, podczas której jedna $\mathrm{z}$ autorek artykułu była jednocześnie osobą prowadzącą zajęcia arteterapeutyczne - zrealizowano łącznie osiem zajęć z zakresu terapii sztuką, każde trwające do dwóch godzin. Dzieci zostały podzielone na dwie grupy ze względu na płeć, przez co każda z nich miała okazję uczestniczyć oraz wypowiedzieć się swobodnie bez obaw, że zostaną ośmieszeni - podział wychowanków był niezwykle ważny ze względu na ich komfort psychiczny. Niejednokrotnie dziewczęta wstydzą się wypowiadać przy swoich kolegach $\mathrm{z}$ grupy, natomiast chłopcy chcąc zamaskować własne zakłopotanie, wyśmiewają się nawzajem lub odmawiają brania udziału w zajęciach z powodu obecności koleżanek. Ze względu na dużą rozbieżność wiekową, wychowankowie nie byli grupowani pod kątem ,,dojrzałości”. Zamiast tego zajęcia były organizowane $\mathrm{w}$ taki sposób, aby zadania nie były zbyt łatwe, a tym samym nudne dla najstarszych uczestników, ale aby jednocześnie najmłodsi mogli je wykonywać bez większych trudności.

Pierwsze zajęcia dotyczyły przyjaźni. Prowadzący połączył biblioterapię oraz teatroterapię, zaś podstawą do przeprowadzenia zajęć były fragmenty Małego Księcia Antoine'a de Saint-Exupéry'ego.

Po wprowadzeniu wychowankowie mieli za zadanie zapoznać się z fragmentami Małego Księcia, odnoszącymi się do przyjaźni głównego bohatera z Różą i Lisem. Następnie odbyła się dyskusja odnośnie do rodzajów koleżeństwa, tego jak powinny wyglądać takie relacje oraz jakie różnice między obojgiem bohaterów widzą uczestnicy. Kolejnym zadaniem było odegranie pantomimy - tematyką było przedstawienie zachowań, jakie mogą występować między przyjaciółmi. Dzieci odgrywały sceny w grupach trzyosobowych, zaś reszta uczestników miała za zadanie odgadnąć, co zostało przedstawione.

Podczas zajęć w obydwu grupach stwierdzono, że zarówno dziewczynki, jak i chłopcy chętnie brali udział w lekcjach, wypowiadając się na zadany temat. Elementy teatroterapii zostały przyjęte z entuzjazmem, zaobserwowano, 
że wychowankowie chętnie wcielili się w zaproponowane przez prowadzącego role, samodzielnie opracowując swoje ,przedstawienie”. Dzięki zajęciom dzieci dowiedziały się, w jaki sposób należy zachowywać się nie tylko wobec swoich najbliższych znajomych, ale również innych osób; wychowankowie usystematyzowali swoją wiedzę na temat prawidłowych postępowań w społeczeństwie.

Sposobność wcielenia się $\mathrm{w}$ rolę pozwoliła im na nieco swobodniejsze zachowywanie, przemyślenie pewnych postępowań (zarówno swoich, jak i cudzych) przez co miały szansę spojrzeć na nie w sposób obiektywny.

Kolejne zajęcia wykorzystywały elementy muzykoterapii oraz choreoterapii - muzyka oraz ruch stanowiły fundament do rozładowania wewnętrznych napięć psychofizycznych, relaksu, a także pobudzenia wyobraźni u uczestników. Terapia zajęciowa, gdzie wykorzystywana jest muzyka, ma pewne stałe elementy - odreagowanie, zrytmizowanie, uwrażliwienie, relaksację i aktywizację. W przypadku pierwszych dwóch oraz ostatniej części można zastosować elementy choreoterapii.

Pierwszym zadaniem dzieci było dobranie się w pary. Na zasadzie „odbicia lustrzanego" pary poruszały się w rytm muzyki, zarówno wolnej i spokojnej, jak i dynamicznej. Kolejną zabawą była gra w ,gorące krzesła” dzieci poruszały się po całej sali w rytm muzyki, zaś gdy ta cichła, musiały usiąść na krześle. Dzięki rozładowaniu napięć psychoruchowych w pierwszej części zajęć dzieci stały się bardziej zrelaksowane, przez co chętniej brały udział $\mathrm{w}$ następnych zadaniach. Trzecim elementem muzykoterapii było uwrażliwienie, a jednocześnie pobudzenie ich wyobraźni poprzez wysłuchanie kilku utworów o różnym natężeniu emocjonalnym i wymyśleniu rozmaitych scenek zgodnie $\mathrm{z}$ odczuciami, jakie towarzyszyły im podczas słuchania dzieł. $Z$ kolei relaksacja polegała na poruszaniu dłońmi po plecach kolegów zgodnie z zasłyszanym dźwiękiem (przykładowo na odgłos deszczu dzieci oklepywały plecy opuszkami palców). Ostatnim elementem była aktywizacja - zabawa przy muzyce, podczas której wychowankowie, wsłuchując się w melodię, naśladowali ruchami rąk grę na instrumentach.

Zajęcia z muzykoterapii i choreoterapii były chętniej odbierane przez chłopców aniżeli przez dziewczynki - wiązało się to prawdopodobnie z większą potrzebą aktywności fizycznej, jaką wykazują chłopcy. W obydwu przypadkach jednak można było zauważyć wpływ muzyki na wyobraźnię u wychowanków; dzieci chętnie opowiadały o historiach lub sytuacjach, jakie przywodziły im na myśl słuchane kompozycje. 
Dodatkowym atutem zastosowania muzykoterapii wobec wychowanków świetlicy środowiskowej była możliwość zapoznania ich z różnymi rodzajami muzyki - od dzieł klasycznych przez utwory filmowe aż po popularne utwory znanych na całym świecie artystów. Jest to bardzo ważne, ponieważ większość z nich nie miała wcześniej do czynienia z większością wariantów - zatem jedne zajęcia dały zarówno sposobność do uwolnienia się od napięć psychofizycznych, jak i zapoznania się z pewnym procentem dorobku kulturowego.

Zajęcia terapeutyczne wykorzystujące muzykę i taniec przyczyniły się równocześnie do wyciszenia dzieci, uspokojenia negatywnych emocji oraz wzmocnienia pozytywnych odczuć.

Elementy relaksacyjne są niezwykle ważne w przypadku zajęć z arteterapii; wychowankowie niejednokrotnie bardzo emocjonalnie podchodzą do wykonywanych zadań, często wzmacniane są uczucia strachu, złości, ale również nadziei i radości. Część rekreacyjna ma za zadanie zneutralizować przeżywane poruszenie, sprawić, by to, co złe, odeszło.

Świetlica środowiskowa oferuje także zajęcia z teatroterapii, które niejednokrotnie łączone są z elementami socjoterapii w celu lepszej socjalizacji dziecka. Wychowankowie przejawiają niekiedy problemy w kontaktach, nie wiedzą, w jaki sposób zachowywać się wobec drugiej osoby lub jak poradzić sobie w danej sytuacji - zatem dla lepszego przyswojenia wiedzy stosowane są zajęcia teatralne, które pozwalają na dokładniejsze zrozumienie wzorów zachowań. Jedne z przeprowadzanych zajęć z teatroterapii dotyczyły bezpiecznego zachowania - improwizowane scenki dotyczyły właściwego postępowania w domu, szkole oraz na zewnątrz. Prowadzący nie narzucał wychowankom konkretnych czynności, zamiast tego dzieci najpierw wymieniały niebezpieczeństwa, a następnie przedstawiały je. Wychowankowie sami wybierali stosowaną metodę teatroterapii. Ci, którzy nie lubią wypowiadać się na forum grupy, zaprezentowali scenki za pomocą pantomimy, inni korzystali z psychodramy. Zauważono, że zajęcia z teatroterapii zezwalają w pewnym stopniu na zyskanie pewności siebie przez dzieci, zaś pozostawiona im swoboda $\mathrm{w}$ działaniu wpływa pozytywnie na rozwój wyobraźni i na pracę w grupie. Z drugiej strony zachęcenie dzieci do „,burzy mózgów” sprawia, że szybciej oraz łatwej zapamiętują pewne sytuacje i wzory postępowań, przez co lepiej przyswajają wiedzę. Z kolei różnorodność form, jakie występują w tym rodzaju zajęć terapeutycznych, pozwala na wykazanie się każdemu wychowankowi, bez względu na jego predyspozycje aktorskie czy też pewność siebie. 
Każde z przeprowadzanych zajęć arteterapeutycznych kończyła dyskusja na przedstawiany temat, podczas której dzieci mówiły, co zapamiętały i zrozumiały z danych działań, jakie formy pracy podobały im się najbardziej, a jakie najmniej. Ostatni element dyskusji pozwalał prowadzącemu na wprowadzanie modernizacji ćwiczeń z zakresu autoterapii, a także rozbudowanie tych zadań, które wpływały pozytywnie na rozwój wychowanków i zostały przez nich entuzjastycznie przyjęte. Dyskusja pozwalała również na dokładniejsze objaśnienie przeprowadzonego tematu oraz umożliwiała dzieciom podzielenie się między sobą wrażeniami i wnioskami, jakie wyciągnęły z zajęć. Końcowa ,pogadanka” była prowadzona w taki sposób, aby każdy z uczestników wypowiedział się swobodnie - dzieci zgłaszały się do odpowiedzi, jednak te, które nie chciały zabierać głosu w rozmowie, nie były do tego przymuszane, a jedynie zachęcane. Zdarzało się, że wraz z rozwojem konwersacji same reagowały na zadawane pytania, niejednokrotnie samemu je zadając - świadczy to o tym, że dzieci mające pozostawianą swobodę w działaniu chętniej biorą udział w zajęciach.

\section{PODSUMOWANIE}

Arteterapia stanowi jedną $\mathrm{z}$ niezwykle ciekawych oraz kreatywnych rodzajów terapii z drugim człowiekiem, dającą sposobność na wyzwolenie emocji za pomocą wszelkich form artystycznych. Najważniejszym elementem ,leczenia” jest pozostawienie wychowankowi jak największej swobody tworzenia, dzięki czemu ma on szansę na wyzbycie się swoich frustracji, lęków i smutku poprzez ,twórcze wyżycie się”.

Zajęcia z arteterapii wspierają rozwój młodego człowieka - jego wyobraźnię, pewność siebie, kreatywność, umiejętność pracy w grupie oraz radzenia sobie z trudnymi emocjami. Osoba prowadząca „kurację sztuką” ma tak naprawdę niekończący się wachlarz możliwości terapeutycznych, z jakich może korzystać, przeprowadzając zajęcia. Mnogość form artystycznych i możliwość łączenia ich ze sobą sprawia, że każde ćwiczenia mogą być zrealizowane w różnych grupach wiekowych czy też dotyczyć najróżniejszych problemów. Arteterapia, prócz łączenia się „,ze sobą”, może być wykorzystywana w innych rodzajach terapii - przykładem może być wykorzystywanie jej elementów w socjoterapii. Na dodatkową uwagę zasługuje fakt, że żadna z wykonanych prac nie jest oceniana pod kątem estetycznym; ma ona jedynie na celu pomoc w wyzbyciu się emocji negatywnych i wzmoc- 
nieniu pozytywnych. Reasumując, terapia przez sztukę stanowi dla pedagoga nie tylko niekończące się źródło pomysłów na przeprowadzenie zajęć, ale może być inspiracją do szukania coraz to nowych dróg i sposobności na zaktywizowanie młodych ludzi do udziału w zajęciach i pokazaniu im możliwości radzenia sobie z problemami.

\section{BIBLIOGRAFIA}

Blotevogel, M., Hitzeler, M., Stegemann, T. (2015). Arteterapie dla dzieci i młodzieży. Muzykoterapia, choreoterapia, terapia sztuka. Gdańsk: Wydawnictwo Harmonia.

CZERniAnin, W., CZERnianin, H. (2014). Biblioterapia jako autonomiczna nauka. Rozważania wstępne. Przegląd Biblioterapeutyczny, 1, 11-34.

GŁAdysZewsKa-Cylulko, J. (2011). Arteterapia w pracy pedagoga. Teoretyczne i praktyczne podstawy terapii przez sztukę. Kraków: Wydawnictwo IMPULS.

GRUDZIEWSKA, E. (2010). Arteterapia jako forma pracy z dzieckiem upośledzonym umysłowo. Szkota Specjalna, 3(254), 194-200.

IPPOLDT, L. (2003). Biblioterapia w związkach z innymi naukami. Annales Academiae Paedagogicae Cracoviensis. Studia Ad Bibliothecarum Scientiam Pertinentia, 2(9), 293-306.

KonIECZnA, E.J. (2004). Arteterapia w teorii i praktyce. Kraków: Wydawnictwo IMPULS.

KoRODZIŃSKA-GraBOWSKA, A. (2012). Arteterapia. Wykorzystanie technik plastycznych w pracy z uczniem przejawiajacym zaburzenia zachowania. Warszawa: Verlag Dashöfer.

KRAN, M. (2001). Taniec jako forma psychoterapii. Arka 36, 23-36.

Matras-Mastalerz, W. (2016). Biblioterapia - ewolucja teorii i rozwój praktyki. Przegląd na podstawie doświadczeń polskich i zagranicznych. Acta Universitatis Lodziensis. Folia Librorum, 1(2), 29-44.

SKRZYPCZYK, W. (2013). Zrozumieć profilaktykę. W: J. WęGRZECKA-GILuŃ (red), Drama i techniki teatralne w promocji zdrowia. Edukacja rówieśnicza (s. 11-35). Warszawa: Wydawnictwo PARPA.

SkwAReK, B., SzULC, W. (2017). Arteterapia w pracy pedagogicznej. Zeszyty Naukowe Państwowej Wyższej Szkoty Zawodowej w Legnicy 22(1), 93-107.

STAŃKO, M. (2009a). Arteterapia - mechanizmy działania z perspektywy neuropsychologii. Psychoterapia 2(149), 29-35.

StAŃKo, M. (2009b). Arteterapia z dziećmi i młodzieżą - perspektywa rozwojowa. Via Medica, $2,66-73$.

\section{ARTETERAPIA INSPIRACJĄ DLA PEDAGOGIKI}

\section{STRESZCZENIE}

Arteterapia jest jedną z możliwości pomocy dzieciom i młodzieży poprzez wykorzystywanie niemal każdego rodzaju twórczości artystycznej. Wszelkie zajęcia związane ze sztuką są najczęściej przez nie postrzegane jako konieczność wykazania się talentem i stworzenia wizualnie pięk- 
nego dzieła - z tego powodu niechętnie biorą one udział w tego typu aktywnościach. Zadaniem pedagoga jest przedstawienie arteterapii nie jako typowych zajęć artystycznych znanych wychowankom ze szkoły, a ,lekcji” gdzie mają szansę na uwolnienie swoich emocji, odreagowanie stresu, a przede wszystkim nauczenie się pewnych rzeczy poprzez zabawę. Ten rodzaj terapii stanowi dla pedagoga niekończące się źródło inspiracji dzięki mnogości oferowanych twórczości artystycznych. $\mathrm{Z}$ tego powodu każde przeprowadzane zajęcia mogą być niezwykle ciekawe i interesujące dla młodego człowieka, przez co będzie chętniej brał w nich udział.

Słowa kluczowe: arteterapia; inspiracja; neutralizowanie emocji; pedagog; dziecko; młodzież.

\section{ART THERAPY IS AN INSPIRATION FOR PEDAGOGY}

\section{SUMMARY}

Art therapy is one of the ways to help children and young people by using almost any type of artistic creation. All classes related to art are most often perceived by them as demonstrating talent, creating a visually beautiful work - for this reason they are reluctant to take part in such activities. The pedagogue's task is to present art therapy not as typical art classes known to pupils from school, but as "lessons" where they have the chance to release their emotions, relieve stress, and above all learn certain things through play. This type of therapy is an endless source of inspiration for the teacher thanks to the multitude of artistic works offered. For this reason, each conducted class can be extremely interesting for a young person, which is why he will be more willing to take part in them.

Key words: art therapy; inspiration; neutralization of emotions; educator; child; youth. 